\title{
Foreign Direct Investment Flow to Africa: Does Natural Resources Matter?
}

\author{
Philip Agyei Peprah ${ }^{1}$, Yao Hongxing ${ }^{1} \&$ Alex Boadi Dankyi ${ }^{1}$ \\ ${ }^{1}$ College of Finance and Economics, University of Jiangsu, Zhenjiang, China \\ Correspondence: Yao Hongxing, College of Finance and Economics, School of Management, University of \\ Jiangsu, Zhenjiang, 212013, China. Tel: 86-511-8879-2098. E-mail: hxyao@ujs.edu.cn
}

Received: June 27, 2019

Accepted: August 20, 2019

Online Published: August 25, 2019

doi:10.5539/ijef.v11n9p67

URL: https://doi.org/10.5539/ijef.v11n9p67

\begin{abstract}
In this study, it explored connections between FDI inflows and natural resource. The paper is an effort to investigate a sample of 10 most resourced sub-Sahara African countries and examine the influence of natural resources on FDI inflow. Further, natural resource wealth is reflected to weaken the FDI inflow. This study discovers if the natural resource overflow affects the FDI inflows. By means of panel data for a sample dated 1990-2017, the paper employed fixed effects method and settles that natural resource slows down FDI inflow of the host nation. The results indicate that economic growth, labor force, trade openness and financial development framework promote FDI inflow in Sub-Sahara Africa countries. The study proposes that FDI inflow to SSA is not only driven by the availability of natural resources in a country but by some exogenous factors, countries with non-existence of natural resources and can obtain FDI by cultivating their bodies and policy environment. Second, multifaceted organizations like the IMF and the World Bank can play a significant role in assisting FDI by encouraging good organisations in SSA.
\end{abstract}

Keywords: Foreign Direct Investment (FDI), natural resources, Sub Sahara Africa, fixed effects, random effects

\section{Introduction}

Since the 2000s, foreign direct investment (FDI) streams to least developed nations have expanded significantly as commodity prices flooded in universal markets notwithstanding satisfactory liquidity in the worldwide economy, joined by the appropriation of market-situated changes in numerous countries (Dabla-Norris, Honda, Lahreche, \& Verdier, 2010). In any case, as of late, worldwide FDI inflows have diminished due to the worldwide financial crisis in 2007/2008. This downward pattern has uplifted challenge among developing countries as they try to pull in these investments from various sources (Van Bon, 2019).

Policies intended to draw in FDI have turned into a vital piece of the more extensive policy need of emerging countries, halfway because of potential advantages of these investments to these economies (Newman, Rand, Talbot, \& Tarp, 2015). FDI is especially significant for Africa particularly in the sub-Saharan African region where most nations are described by immature financial markets. Because of this issue, most of nations in this part of the world have not had the option to assemble adequate internal resources to meet domestic investment necessities. Therefore, FDI is considered as a significant vehicle for accessing foreign resources so as to connect the financing hole and supplement domestic investments, in this manner advancing growth, job creation and easing poverty in host nations (Zekarias, 2016). In light of the apparent advantages of FDI, most African nations have embraced policy reforms so as to lessen boundary and draw in these investments (Moss, Ramachandran, \& Shah, 2005).

FDI is perceived as an impetus for invigorating growth and development, particularly in numerous developing countries that have constrained ability to advance domestic investment and finance long haul development (Mahembe \& Odhiambo, 2013). FDI is seen as a necessary segment of financial globalization (Campos \& Kinoshita, 2003b; Pehnelt, 2007) due halfway to potential advantages to these nations. In late decades, it has developed at a quicker pace than trade streams between nations (Blonigen, Davies, Waddell, \& Naughton, 2007).

As of late, FDI is considered as a critical method for changing technologies, improving financial development and diminishing poverty around the world. Thus, policy makers in both created and creating nations have acquainted policies with pull in more FDI. As per the (UNCTAD), foreign capital injections are essential to the 
crane nation, as inward FDI adds to economic improvement through giving new knowledge generation, job establishment, and promoting competitiveness (E. Asiedu, 2013a).

In most African economies there is an overreliance of governments and administration on natural resource revenue e.g. in countries where there are extractive minerals like gold and oil. Some writers suggest that the discoveries of these resources are somehow a curse and not benefits. Natural resource exportations are related with more slow growth rate (Sachs \& Warner, 2001) therefore such gathering of FDI in the resource sector is relied upon to fuel the natural resource curse further and refute any potential development instigating influence of FDI.

The motivation behind this paper is to research on the effect of natural resources on empowering and advancing foreign direct investment (FDI) inflows in Africa. Breaking down the proportions of natural resource, as far as all out regular assets with the goal of acquiring quantitative estimates on its association with FDI inflows in Africa. The remainder of the paper is sorted out as the accompanying. Literature Review is displayed in section II and is trailed by data, model and data analysis in section III. Empirical findings are displayed in section IV while section $\mathrm{V}$ finishes up the paper with policy implications.

\section{Literature review}

There are broad thoughts that countries rich in natural resources, for example, extractive minerals, propel more FDI, yet this isn't generally the situation. The effect of natural resources on FDI is as yet a dubious issue, with proof of instigating positive and negative impacts. World Development Indicators (2013) noticed that "states that depend on vigorously extractive sectors have seen huge increments in natural resource rents, however their growth won't be sustainable except if they invest in productive resources" (Bokpin, Mensah, \& Asamoah, 2015).

The recent studies have concentrated on the explicit connexion between FDI inflows, outflows, and natural resources. Most of these revisions take the massing impact, through FDI mechanisms into account. Poelhekke and van der Ploeg (2010b) among the first studies has endeavoured to reveal insight into this subject. They analyse whether natural resources draw in FDI, covering outflows FDI from Dutch firms to 183 countries over the time period of 1984-2002 adopting a gravity panel data model. By separating between FDI outwards to resource and non-resource sectors, they set up two econometric models, one for resourced and another for non-resource FDI. They assessed that subsoil properties as a proxy of natural resources prompt an antagonistic effect on non-resource FDI, however positively affect resource FDI. Likewise, they argued that the neat impact of resource wealth on absolute FDI rapidly ends up negative utilizing recreation work out.

The most important astounding outcome is that good quality of institutions and exchange receptiveness has insignificant impacts on foreign direct investment on the non-resource sector whereas good institutions has a positive effect on asset FDI.

Also, E. Asiedu (2013b) proof that repudiates her prior investigation in 2002, E. Asiedu (2013b) uncovered a negative association between natural resources (characterized as the portion of fuel export altogether reports and oil rents-GDP ratio). The author utilized the GMM technique to estimate net FDI inflows-gross domestic product proportion on natural resources, quality of institutions and control variables like exchange receptiveness, inflation and GDPPC in 99 creating nations amid 1984-2011. The after effects of this study outline that natural resource negatively affects FDI by 0.05 .

As the same way this outcome was steady with (Poelhekke, van der Ploeg, \& Statistics, 2013; Poelhekke \& van der Ploeg, 2010a), in any case, E. Asiedu (2013b) reasoned that best institutional quality could moderate the unfavourable impact of natural resources and condemned Poelhekke and van der Ploeg determinations by utilizing a wide range of methods of quality of institutions. Asiedu depicted this negative association as a swarming out impact. Campos and Kinoshita (2003a) examined the elements of FDI inflows to 25 emerging nations from 1990 to 1998 utilizing one of a kind panel data. They found that natural resource plenitude pulled in secured to these countries.

The study of Asiedu (2006) she utilized in a panel of twenty two African nations and finds, for example, that natural resources and huge markets advance FDI. In a similar vein, Basu and Srinivasan (2002) locate that some African countries have had the option to pull in FDI not in light of natural resources, yet through an expansive improvement in the whole business condition and intentional picture enhancing crusades. Once more, E. Asiedu and Lien (2011a) as of late set up that natural resource export force adverse effects FDI. Subsequently, an end on the genuine effect of resource endowment might be impacted by measurement-related issues.

Elheddad (2016) in his study came out that natural resources estimated by oil rents have an adverse relationship with inwards foreign direct investment; this worsen effect is appropriate even when other determinants of FDI 
are considered. Inwards foreign direct investment reduced between $0.15 \%$ and $0.92 \%$ when oil rents enhanced by $1 \%$.

Poelhekke and van der Ploeg (2013) extensively explained that in front of the pack, for economies which were not formerly resource generators, a resource revelation causes non resource FDI to reduce $16 \%$ and $68 \%$ in both short-run and long-run. Besides, they recorded that for nations that were at that point a resource generator; a multiplying of resource rents initiates a $12.4 \%$ decrease in non-resource FDI. Besides, the authors expressed that by and large, the compression in non-resource FDI exceeds the blast in resource FDI. Total FDI reduces by $4 \%$ if the resource bonanza is multiplied. At last, they understood that all these negative impacts on non-resource FDI are enhanced through the positive spatial lags in non-resource FDI just as finding that resource FDI is vertical, while non resource FDI is of the export-fragmentation assortment. they recorded a robust distinctive measures of resource saves and the oil price and to permitting sample choice inclination.

Bokpin et al. (2015) in their examination gave that within the sight of specific kind of natural resources, openness of trade or banking segment credit extension or infrastructural expansion is less alluring while territorial or trade openness emphatically restrained the impact of financial market growth and infrastructural progress on FDI stream on the region.

In an examination by Hayat (2018), he investigated if the natural resource wealth influences the FDI growth relationship. Utilizing panel data for an example the period 1993-2012, the paper utilizes fixed effects model and presume that FDI inflow quickens financial progress of the host nation. In any case, the nearness of natural resources backs off the FDI instigated growth. Similar outcomes hold in the wake of controlling for endogeneity. The principle finding is that natural resources and big markets advance FDI. Be that as it may, lower inflation, great infrastructure, an educated populace, openness to FDI, low corruption, political strength and a solid legal framework have a comparable impact. The motivation behind this paper is to research the effect of natural resources on empowering and advancing FDI inflows in Africa. Breaking down the proportions of natural resource, as far as all out regular assets with the goal of acquiring quantitative estimates on its association with FDI inflows in Africa.

\section{Data}

In this section, the data pretty much all the indicators utilized in this study is portrayed. The paper depends on examining data for the time of 28 years from 1990 to 2017 from 10 Sub Saharan African creating countries as indicated by the World Bank criteria. The examination utilized the ratio of net FDI inflow to GDP as reliant variable that is gotten from World Bank database. In request to catch the impacts of natural resource, numerous investigations have utilized different measures of natural resource. This study employed total natural resources rents (\% of GDP) which is consistent with that of Mehar, Hasan, Sheikh, and Adeeb (2018) as a proxy for natural resource and considered as the variable of interest. Other variables were considered as control variables in order to determine the whether natural resource can induce foreign investment in a country. Such variables include Gross Domestic Product used as economic growth (GDP), Labor Force (LAB), Financial development (FIN) and trade openness (TRADE).

Table 1. Variable definition \& source of data

\begin{tabular}{lll}
\hline Variables & Definition & Sources \\
\hline FDI (Foreign Direct Investment Inflow) & The Ratio of FDI Inflow to GDP & WDI \\
GDP (Gross Domestic Product) & Growth of the economy & WDI \\
TNR (Total Natural Resources) & total natural resources rents & WDI \\
LAB (labour Force) & Total number of workers both skilled and unskilled & WDI \\
FIN (Financial Development) & Funds available for private institutions & WDI \\
Trade (Trade Openness) & Ratio of import and export to the gross domestic product & WDI \\
\hline
\end{tabular}

Source: Author Composition.

\subsection{Model}

The objective of this examination depends on the possibility that natural resource blast will in general lead to energy about country's currency, because of that, natural resources will be less competitive. But this implies the natural resource sector swarms out non-resource sectors in regards to FDI (Poelhekke \& van der Ploeg, 2013; Poelhekke \& van der Ploeg, 2010b). Likewise, natural resources, particularly oil, is more varied which makes the country increasingly powerless against outside shocks. By the day's end, FDI flies from the natural resource sector to the non-resource sector, yet this non-resource sector is less aggressive in the world market. 
Following the past literature, the study analyses the determinants of FDI inflow to 10 most natural resourced countries in sub-Sahara Africa. The normal model is as per the following

$$
\left(\frac{F D I}{G D P}\right) i t=\alpha+{ }_{\beta 1} T N R+{ }_{\beta 2} \mathrm{Xit}+\varepsilon \text { ? }
$$

Where FDI is ratio of net FDI inflow to GDP to 10 most natural resourced countries in sub-Sahara Africa, $\alpha$ as the intercept and $X_{i t}$ as vector of control variables such as Gross Domestic Product (GDP), Labor Force (LAB), Financial Development (FIN) and Trade Openness (TRADE). Table 2 below gives the descriptive statistics of the variables under discussion.

\subsection{Data Analysis}

Table 2. Descriptive statistics

\begin{tabular}{ccccccc}
\hline Variable & FDI & GDP & TNR & LAB & FIN & TRADE \\
\hline Obs & 280 & 280 & 280 & 280 & 271 & 272 \\
Mean & 4.012793 & $1.38 \mathrm{e}+10$ & 11.04174 & 8975320 & 31.30598 & 68.75438 \\
Std. Dev. & 5.465248 & $9.82 \mathrm{e}+09$ & 8.156052 & 7336686 & 49.05814 & 23.58614 \\
Min & -6.89768 & $2.28 \mathrm{e}+09$ & .3737312 & 447036 & -79.09235 & 25.01345 \\
Max & 41.80964 & $5.06 \mathrm{e}+10$ & 37.37866 & $2.79 \mathrm{e}+07$ & 192.66 & 146.7666 \\
\hline
\end{tabular}

Source: Authors Calculations.

Table 3. Unit root estimation

\begin{tabular}{|c|c|c|c|c|}
\hline \multirow{2}{*}{$\begin{array}{c}\text { Im-Pesaran-Shin Unit-Root Test } \\
\text { Variables }\end{array}$} & \multicolumn{2}{|c|}{ Level Panel Means: Indvidual Intercept } & \multicolumn{2}{|c|}{$\begin{array}{l}1^{\text {st }} \text { Dif Panel Means: Included } \\
\text { Time Trend: Not Included }\end{array}$} \\
\hline & T.Statistics & Prob & T.Statistics & Prob \\
\hline FDI & -1.2851 & 0.6371 & -21.221 & $0.0000^{* * *}$ \\
\hline GDP & 7.2248 & 1.0000 & -2.9729 & $0.0388 * *$ \\
\hline TNR & -1.3336 & 0.6144 & -8.5112 & $0.0000^{* * *}$ \\
\hline LAB & 4.0720 & 1.0000 & -8.4268 & $0.0000^{* * *}$ \\
\hline FIN & -0.5732 & 0.8724 & -113.70 & $0.0001 * * *$ \\
\hline TRADE & -1.0075 & 0.7510 & -32.786 & $0.0001 * * *$ \\
\hline
\end{tabular}

NB: *** Significant at the $1 \%$ level, ** Significant at the 5\% level, * Significant at the $10 \%$ level. Source: Authors' Calculations.

Table 4. Correlation matrix

\begin{tabular}{ccccccc}
\hline Variable & FDI & GDP & TNR & LAB & FIN & TADE \\
\hline FDI & 1.0000 & & & & & \\
GDP & 0.1012 & 1.0000 & & & & \\
TNR & 0.1836 & 0.2041 & 1.0000 & & & \\
LAB & 0.0350 & 0.6041 & 0.3765 & 1.0000 & & \\
FIN & -0.0468 & 0.1208 & -0.2070 & 0.3515 & 1.0000 & 1.0000 \\
TRADE & 0.4323 & -0.0449 & -0.0751 & -0.4264 & -0.1262 & \\
\hline
\end{tabular}

Source: Authors Calculations.

Table 5. Regression analysis

\begin{tabular}{lll}
\hline Variables & Fixed Effects & Random Effects \\
\hline GDP & $(-1.72 \mathrm{e}-10)$ & $(-3.29 \mathrm{e}-11)$ \\
& {$[4.57 \mathrm{e}-11]^{* * *}$} & {$[3.96 \mathrm{e}-11]$} \\
TNR & $(.0061994)$ & $(.0899746)$ \\
& {$[.0475521]$} & {$[.045187]^{* *}$} \\
LAB & $(2.37 \mathrm{e}-07)$ & $(2.04 \mathrm{e}-07)$ \\
& {$[6.85 \mathrm{e}-08]^{* * *}$} & {$[6.96 \mathrm{e}-08]^{* * *}$} \\
FIN & $(-.0142013)$ & $(-.0044338)$ \\
& {$[.0070744]^{* *}$} & {$[.007077]$} \\
TRADE & $(.0940367)$ & $(.1319026)$ \\
& {$[.0157497]^{* * *}$} & {$[.0150198]^{* * * *}$} \\
Prob & 0.0000 & 0.0000 \\
\hline
\end{tabular}

NB: ( ) and [ ] represents values of coefficients and std. error respectively. $* * *, * *$ represents significance at $1 \%$ and $5 \%$ respectively. Source: Authors Calculations. 
Table 6. Hausman test results

\begin{tabular}{lccc}
\hline Test Summary & Chi-Sq. Statistic & Chi-Sq. d.f. & Prob. \\
\hline Cross-section random & 31.94 & 3 & 0.0000 \\
\hline
\end{tabular}

Source: Authors Calculations.

\section{Empirical Results}

This paper utilizes long panel data for the period 1990-2017 ( $\mathrm{T}=28, \mathrm{~N}=10$ ). Therefore, the study organizes in assessing the empirical results is to check for spurious outcomes. This should be possible by applying panel data unit root estimations. There are around four diverse board unit root tests. They are Im, Pesaran and Shin (IPS), Levin, Lin and Chu (LLC) and etc. This investigation utilized the Im, Pesaran and Shin (IPS) method for the estimation of unit root. Table 2 gives the results of the characteristics of the variables as well as the unit root estimation in Table 3 with the null hypothesis that there is unit root in sample and the alternative as there is no unit root in sample. The results above indicate that all variables are stationary thus there is no unit root (stationary) at level with a lag of 1 meaning they are all stationary at $\mathrm{I}(\mathrm{O})$.

The correlation statistics are displayed in Table 4 above to put it plainly, data differ enough with the goal that one can capture applicable correlations between the reliant variable and independent variables. Besides, the results of correlations between explanatory variables (Table 4) recommends that the incorporation of all these variables in a similar model represent no issue of multicollinearity. In fact, coefficients of correlation show up very low overall.

Table 5 displays the consequences of both the fixed and random effects estimations, in view of two arrangements of equation 1 with the ratio of inward FDI to GDP as the reliant variable. The hausman test result in Table 6 recommend that the proper strategy for estimation is the fixed effects technique. Beginning with the principle variable of interest in this manner total natural resource (TNR) against the reliant variable, the TNR variable in the functional regressions has no significant impacts on foreign direct investment meaning the no sum or the presence of natural resources in a nation will warrant foreign investment. Statistically, it very well may be demonstrated that TNR have poor relationship with foreign investment as delineated by the coefficient value of (0.0061994) which affirms the dynamic nature of the progression of inward FDI in the district. The outcomes above are against the desire and the previous finding by Asiedu (2006)called attention to that the mineral and oil exports-total exports proportions as an intermediary of natural resource has a critical job in pulling in FDI inflows, taking 22 African nations as a sample amid (1984-2000) and utilizing panel data investigation. and which is likewise predictable. In a similar line, Hailu (2010) inspected the demand side causes influencing foreign capital inflows over the period. Haile found that natural resource (mineral depletion as an offer in GNI) is positively and significantly related with FDI ratio. A One percent increment in natural resources results in effect somewhere in the range of 0.500 and 0.19 percent.

The coefficients of the intermediaries for financial development in relapse equations portrays that a 1 percent expansion in financial development as in domestic credit issued by banks to private sector will result in an equal percentage in rise foreign investment. On the opposite side financial development have a significant impact on foreign investment at 5\% significance level. Steady with theoretical recommendations, financial development can improve the progression of FDI just when it is ready to play key allocative, exchange cost decrease, the liquidity, and monetary enforcement contract jobs. (Shah, 2016) affirmed this in an investigation and he stated that financial development through random effects panel estimation strategy the findings of the examination proposes that financial development is a robust indicator of FDI inflows in the MENA region.

However, the other explanatory variables thus GDP, LAB and TRADE are more significant in the regression equation. It can be noted from the results that these variables are significance at $1 \%$ significant level with coefficients of $-1.72 \mathrm{e}-10,2.37 \mathrm{e}-07$ and .0940367 respectively. An examination conducted by Iamsiraroj and Doucouliagos (2015) which the existence of a robust positive connection amongst growth and FDI. Significantly bigger relationships are built up for individual country case studies than with cross-country investigation. It moreover creates the impression that growth is somewhat increasingly corresponded with FDI in creating countries. the connection with FDI stream is generally positive however non-significant can be clarified dependent on the projection of the growth theory that a developing economy signals better open doors for making profits and is steady with the current evidence in the writing that high growth markets are emphatically linked with stable macroeconomic situations and are increasingly alluring to foreign investments (Chakrabarti, 2001). Steady with the outcomes E. Asiedu and Lien (2011b) stated that the coefficient of GDP in the majority of the diverse function regressions is negative and indeed, even significant at $1 \%$ level in the condition on FDI 
inflows. In spite of the fact that this outcome appears to strife with the market size hypothesis, it does bolsters the position of Ezeoha and Cattaneo (2012) that the effect of the extent of a country's economy is touchy to various kinds of FDI streams.

The significant nature of skilled labour force on foreign investment is consistent with a study by Bayraktar-Sağlam and Sayek Böke (2017) who hypothesised that sectoral composition of FDI and the decomposition of labor assume a significant job in investigating the dynamic relationship among labor and. Lastly, trade openness from the outcomes above indicates that there is a cordial and positive relationship between foreign investment and trade openness. Statistically, is can be stated that a unit increase in trade openness will equally result a 0.09 increase in foreign investment inflows. A research study by Asiedu (2002) openness to trade elevates FDI to SSA and non-SSA nations; be that as it may, the minimal profit by increased openness is less for SSA. These outcomes infer that Africa is extraordinary-proposing that arrangements that have been effective in different districts may not be similarly fruitful in Africa.

\section{Conclusions and Policy Implications}

This paper has examined the effects of natural resources on FDI inflow to Africa. The results indicate that economic growth, labor force, trade openness and financial development framework promote FDI inflow in Sub-Sahara Africa countries. In contrast, total natural resource has the opposed effect.

These outcomes are consistent with the results of some early writers on the study of natural resource on FDI inflows. The outcome has numerous policy implications. First, it proposes that FDI inflow to SSA is not only driven by the availability of natural resources in a country but by some exogenous factors, countries with non-existence of natural resources and can obtain FDI by cultivating their bodies and policy environment. Second, multifaceted organizations like the IMF and the World Bank can play a significant role in assisting FDI by encouraging good organisations in SSA (E. Asiedu \& Villamil, 2003; Frankel, Birdsall, Sachs, \& Ortiz, 2003; Hakura \& Nsouli, 2003). The outcomes additionally recommend that economic collaboration may upgrade FDI inflow to the region (Moreira, 2008).

At long last, it is essential to take note of that expanded FDI inflow does not really infer higher economic growth. In reality, the empirical connection between FDI inflow and growth is unclear .22 Some investigations have discovered a positive connection between FDI inflow and economic growth (De Gregorio, 2005; Oliva \& Rivera-Batiz, 2002).

\section{References}

Asiedu, E. (2013). Foreign direct investment, natural resources and institutions. International Growth Centre, Working Paper Series.

Asiedu, E., \& Lien, D. J. J. O. I. E. (2011). Democracy, foreign direct investment and natural resources. Journal of International Economics, 84(1), 99-111. https://doi.org/10.1016/j.jinteco.2010.12.001

Asiedu, E., \& Villamil, A. P. (2003). Promoting Efficient Institutions and Providing Insurance Services: A Dual Role for Multilateral Agencies. Available at SSRN 416721. https://doi.org/10.2139/ssrn.416721

Asiedu. (2002). On the determinants of foreign direct investment to developing countries: is Africa different? World Development, 30(1), 107-119. https://doi.org/10.1016/S0305-750X(01)00100-0

Asiedu. (2006). Foreign direct investment in Africa: The role of natural resources, market size, government policy, institutions and political instability. World Economy, 29(1), 63-77. https://doi.org/10.1111/j.1467-9701.2006.00758.x

Basu, M. A., \& Srinivasan, M. K. (2002). Foreign direct investment in Africa: Some case studies. International Monetary Fund. https://doi.org/10.5089/9781451848182.001

Bayraktar-Sağlam, B., \& Sayek Böke, S. (2017). Labor costs and foreign direct investment: A panel VAR approach. Economies, 5(4), 36. https://doi.org/10.3390/economies5040036

Blonigen, B. A., Davies, R. B., Waddell, G. R., \& Naughton, H. T. (2007). FDI in space: Spatial autoregressive relationships in foreign direct investment. European Economic Review, 51(5), 1303-1325. https://doi.org/10.1016/j.euroecorev.2006.08.006

Bokpin, G. A., Mensah, L., \& Asamoah, M. E. (2015). Foreign direct investment and natural resources in Africa. Journal of Economic Studies, 42(4), 608-621. https://doi.org/10.1108/JES-01-2014-0023

Campos, N. F., \& Kinoshita, Y. (2003a). Why does FDI go where it goes? New evidence from the transition economies. https://doi.org/10.2139/ssrn.414540 
Campos, N. F., \& Kinoshita, Y. (2003b). Why does FDI go where it goes? New evidence from the transition economies. Papers.ssrn.com. https://doi.org/10.2139/ssrn.414540

Chakrabarti, A. J. K. (2001). The determinants of foreign direct investments: Sensitivity analyses of cross country regressions. Kyklos, 54(1), 89-114. https://doi.org/10.1111/1467-6435.00142

Dabla-Norris, E., Honda, J., Lahreche, A., \& Verdier, G. (2010). FDI flows to low-income countries: Global drivers and growth implications. IMF Working Papers, 1-38. https://doi.org/10.5089/9781455209408.001

De Gregorio, J. (2005). The role of foreign direct investment and natural resources in economic development. In Multinationals and Foreign Investment in Economic Development (pp. 179-197): Springer. https://doi.org/10.1057/9780230522954_9

Elheddad, M. M. (2016). Natural resources and FDI in GCC Countries. International Journal of Business Social Research, 6(7), 12-22. https://doi.org/10.18533/ijbsr.v6i7.977

Ezeoha, A. E., \& Cattaneo, N. (2012). FDI flows to sub-Saharan Africa: The impact of finance, institutions, and natural resource endowment. Comparative Economic Studies, 54(3), 597-632. https://doi.org/10.1057/ces.2012.18

Frankel, J. A., Birdsall, N., Sachs, J., \& Ortiz, G. (2003). Panel discussion: Promoting better national institutions: The role of the imf. IMF Staff Papers, 50, 21-40. https://doi.org/10.2139/ssrn.392401

Hailu, Z. A. (2010). Demand side factors affecting the inflow of foreign direct investment to African countries: does capital market matter? International Journal of Business Management, 5(5), 104. https://doi.org/10.5539/ijbm.v5n5p104

Hakura, D., \& Nsouli, S. M. (2003). The millennium development goals, the emerging framework for capacity building, and the role of the IMF. IMF Papers. https://doi.org/10.5089/9781451854190.001

Hayat, A. (2018). FDI and economic growth: the role of natural resources? Journal of Economic Studies, 45(2), 283-295. https://doi.org/10.1108/JES-05-2015-0082

Iamsiraroj, S., \& Doucouliagos, H. (2015). Does growth attract FDI? https://doi.org/10.5018/economics-ejournal.ja.2015-19

Mahembe, E., \& Odhiambo, N. M. (2013). The dynamics of foreign direct investment in SADC countries: Experiences from five middle-income economies. Problems \& Perspectives in Management, 11(4), 35-45.

Mehar, M. R., Hasan, A., Sheikh, M. A., \& Adeeb, B. (2018). Total Natural Resources Rent Relation with Economic Growth: The Case of Pakistan and India. European Journal of Economic \& Business, 3(03).

Moreira, S. B. (2008). The determinants of foreign direct investment: What is the evidence for Africa? ÁFrica Esuas Diásporas: Olhares Interdisciplinares, 105-138.

Moss, T., Ramachandran, V., \& Shah, M. (2005). Is Africa's scepticism of Foreign capital justified? Evidence from East African survey data (pp. 337-367). Center for Global Development, Washington DC.

Newman, C., Rand, J., Talbot, T., \& Tarp, F. (2015). Technology transfers, foreign investment and productivity spillovers. European Economic Review, 76, 168-187. https://doi.org/10.1016/j.euroecorev.2015.02.005

Oliva, M. A., \& Rivera-Batiz, L. A. (2002). Political institutions, capital flows, and developing country growth: An empirical investigation. Review of Development Economics, 6(2), 248-262. https://doi.org/10.1111/1467-9361.00152

Pehnelt, G. (2007). Globalisation and inflation in OECD countries. Jena Economic Research Paper (2007-055). https://doi.org/10.2139/ssrn.1022901

Poelhekke, S., \& van der Ploeg, F. (2013). Do natural resources attract nonresource FDI? Review of Economics Statistics, 95(3), 1047-1065. https://doi.org/10.1162/REST_a_00292

Poelhekke, S., \& van der Ploeg, R. (2010a). Do natural resources attract FDI? Evidence from non-stationary sector level data. https://doi.org/10.2139/ssrn.1950092

Poelhekke, S., \& van der Ploeg, R. (2010b). Do natural resources attract FDI? Evidence from non-stationary sector level data. Papers.ssrn.com. https://doi.org/10.2139/ssrn.1950092

Sachs, J. D., \& Warner, A. M. (2001). The curse of natural resources. European Economic Review, 45(4-6), 827-838. https://doi.org/10.1016/S0014-2921(01)00125-8

Shah, M. H. (2016). Financial development and foreign direct investment: The case of Middle East and North 
African (MENA) developing nations. University of Haripur Journal of Management, 1(2), 93-109. .

Van Bon, N. (2019). The Role Of Institutional Quality In The Relationship Between Fdi And Economic Growth In Vietnam: Empirical Evidence From Provincial Data. The Singapore Economic Review, 64(3), 601-623. https://doi.org/10.1142/S0217590816500223

Zekarias, S. M. (2016). The impact of foreign direct investment (FDI) on economic growth in Eastern Africa: Evidence from panel data analysis. Applied Economics Finance, 3(1), 145-160. https://doi.org/10.11114/aef.v3i1.1317

\section{Copyrights}

Copyright for this article is retained by the author(s), with first publication rights granted to the journal.

This is an open-access article distributed under the terms and conditions of the Creative Commons Attribution license (http://creativecommons.org/licenses/by/4.0/). 